\title{
Acquired Knowledge, Skills and Abilities of Graduates of Business Administration of Graduate Education of Neust
}

\author{
Delilah Pangilinan, Arriane Garcia Juan, Marilou Pascual, Mercedes Santos, \\ Richard Simangan
}

\begin{abstract}
This study was done to find out the current employment status of graduates after acquiring Masteral and Doctorate in Nueva Ecija University of Science and Technology for A.Y. 2013 -2019. It also described the school-and work-related factors which might affect their employability after getting the degree from NEUST. It also assessed the extent by which work knowledge, skills and abilities thru education have bearing with their current work. Findings showed that the majority of graduates were employed and got promoted. They studied the course primarily for professional advancement, as an institutional requirement and gain management skills. Entrepreneurial and problem-solving skills were the foremost competencies acquired from school. They also found very important the teacher communication skills, professionalism and mastery of the subject to be very relevant too in their education.
\end{abstract}

Keywords-knowledge; skills; abilities; Graduate Education.

\section{INTRODUCTION}

A tracer study is a research that involves tracing the alumni of an institution to find the alumni's current situation, and how the knowledge they attained helped them in their daily lives and the skills enhanced from the education they were given [1].In addressing the emerging and complex nature and challenges of the 21st century, higher education stands out as one of the major keys to cope with reforms. Through its essential functions of instruction, research, extension and production, higher education makes-up a vital and strategic part in development [2]. Tracer study can also be used in evaluating the results of their education because it reviews the transition between the educational and the professional world, how high a position in the work place they can attain the worth of the condition of educational institution of their career [1].Recognizing the reality in today's academic world, the role of higher education institutions can not only be limited to impart knowledge, but also to contribute to maintain a competitive economy and most important of all, to secure the dream of graduates to get jobs and become socially recognized and successful in their respective field of endeavors. On the other hand, one of the major factors for underemployment and the difficulty in finding jobs is the inability of graduates to meet the necessary skills and competencies required by the industry [3]. Master of business administration (MBA), a masteral degree in business administration can be achieved at a university or college that provides theoretical and practical training to help graduates attain a wider understanding in the functions of general business management. The MBA degree has different focuses such as accounting, finance, or marketing. While the Doctorate in philosophy (Ph.D.) in business addresses substantial accounting issues with theories and methods. In this study, the respondents are the graduates of Nueva Ecija University of Science and Technology A.Y. 2013-2019. The goal of the Master of Business Administration (MBA) program is to add value to the graduates andprovides them with certain competencies to make them better managers and leaders [4].It has assisted participants in developing basic management and administration skills [5]. This is seen in increased managerial skills, self-confidence and several aspects of career development [6].

\section{OBJECTIVE OF THE STUDY}

This tracer study aimed to trace the graduates of MBA and $\mathrm{Ph} . \mathrm{D}$. in Business Administration programs from Nueva Ecija University of Science and Technology Graduate School on 2013-2019. The objective of this study aimed to describe the profile and current employment of MBA and 
Ph.D. graduates. Determined the school-related factors that affect the graduate's employability and promotion [3].

\section{RESEARCH METHODOLOGY}

Research Method. Descriptive research design was used to trace the graduate's employability and employment status, and the impact of acquired knowledge, skills and abilities of the respondents who were chosen purposively based on the following criteria [7]:They have finished their Master of Administration and Doctor of Philosophy in Nueva Ecija University of Science and Technology Graduate School during 2013-2019.Out of the total 125 graduates, 92 or $73.6 \%$ were surveyed. They are broken down as follows: The figure 1 shows that 92 of respondents were equivalent to $100 \%$, MBA graduates got a total number of 81 or $88.04 \%$ and $\mathrm{Ph}$. D. respondents consist of 11 or $11.96 \%$ were able to finish the course.

\section{Figure 1. Distribution of Educational Attainment of Respondents, 2013-2019}

\section{$\mathrm{N}=92$}

Column 1

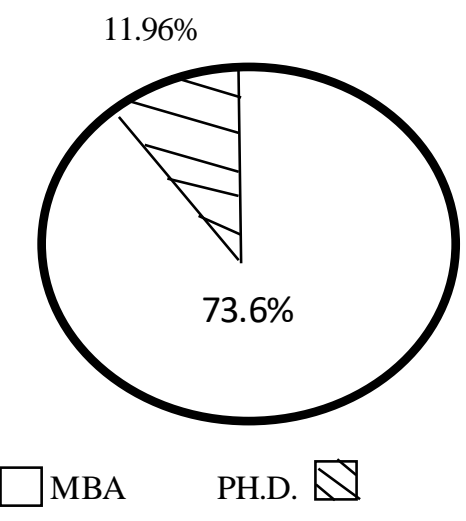

Instrument. The main instrument used in the study was a questionnaire with an unstructured interview, the educational background, employment history, and the checklist as follows; reasons why the respondents decided to study at NEUST, competencies and skills attained from school to job placement of the respondents.

Procedure. Names of the graduates from 2013-2019 were obtained from the office of registrar of Nueva Ecija University of Science and Technology. The said questionnaire was personally distributed by the researchers to the respondents.
Data Analysis. The collected data were categorized, tabulated and coded for analysis. The following statistical tools were employed using frequency and percentage.

\section{FINDINGS}

The data gathered from the respondents about the research objectives are as followed.

Table 1. Status of employment

\begin{tabular}{|l|c|c|}
\hline Response & $\begin{array}{c}\text { Frequency } \\
\boldsymbol{f}\end{array}$ & $\begin{array}{c}\text { Percentage } \\
(\boldsymbol{\%})\end{array}$ \\
\hline Employed & 83 & 90 \\
\hline Self-employed & 9 & 10 \\
\hline TOTAL & 92 & $100 \%$ \\
\hline
\end{tabular}

The table shows the frequency distribution of the respondents that $90 \%$ were employed, while the other $10 \%$ were engaged in another line of business. It shows that the majority of them were employed in the past.

Table 2. Frequency Distribution of the Respondents According to their Occupational Classification

\begin{tabular}{|l|c|c|}
\hline Occupational Classification & f & \% \\
\hline Entrepreneur & 9 & 9.78 \\
\hline Private Agency & 21 & 22.83 \\
\hline Government Agency & 62 & 67.39 \\
\hline Total & 92 & 100 \\
\hline
\end{tabular}

The table 2 shows that the frequency distribution of the Respondents according to their occupational classification. Out of 92 respondents, $67.39 \%$ were in the government, while $22.83 \%$ were in the private agency and 9 or $9.78 \%$ were entrepreneurs.

Table 3. Past Employment History of the Respondents

\begin{tabular}{|l|c|c|}
\hline \multirow{2}{*}{ Status } & \multicolumn{2}{|c|}{ Present } \\
\cline { 2 - 3 } & f & \% \\
\hline Contractual & 30 & 36.14 \\
\hline Permanent & 53 & 63.86 \\
\hline Total & 83 & 100 \\
\hline
\end{tabular}

Table 3 shows that the contractual status decreased from previous to current employment, while those regularly employed retained the employed and at the same time promoted in work. 
Table 4. Distribution of the Respondents According to their Present Employment

\begin{tabular}{|l|c|c|}
\hline Present status & f & \% \\
\hline Regular/Permanent & 48 & 57.83 \\
\hline Contractual/Temporary & 26 & 31.33 \\
\hline Self-employed & 9 & 10.84 \\
\hline Total & 83 & 100 \\
\hline
\end{tabular}

More of the Respondents were in temporary status and the rest of them were either regular or permanent and there some who practiced their major in the field of business because of the experienced and more preferred.

Table 5. Distribution of the Respondents According to their income

\begin{tabular}{|l|c|c|}
\hline Salary & f & \% \\
\hline P 10,000-below & 2 & 2.41 \\
\hline P 10,001-above & 72 & 87.80 \\
\hline Total & 74 & 90.21 \\
\hline
\end{tabular}

The bracket P10,001 - above salaries received by BSBA alumni could indicate that they are already in regular employment status. Only a few could be considered in managerial position above this scale. It could also signify competency (qualification) on the part of these graduates. Skills and experience play a vital role in one's promotion, according to respondents. According to Table 4, nine respondents are currently self-employed with no fixed income due to this, the nine respondents are not imputed in Table 5.

Table 6. Reasons Why Respondents Decided to Study at NEUST

\begin{tabular}{|l|c|c|}
\hline Reasons & f & \% \\
\hline Professional Advancement & 89 & 96.74 \\
\hline Institutional Requirement & 71 & 77.17 \\
\hline Low / No Tuition Fees & 64 & 69.57 \\
\hline $\begin{array}{l}\text { Reputation of the School/ } \\
\text { Training Institution }\end{array}$ & 87 & 94.57 \\
\hline Referral by Co-Employees & 31 & 33.7 \\
\hline
\end{tabular}

Majority of the graduates' reasons were professional advancement, the reputation of the school/training institution, institutional requirement. It implies that graduates want to be more competitive in our society. Also, the graduates know that NEUST have good records and reputation in education and it trains the students to make accurate decisions given available information [8] which they can utilize in their workplace.

Table 7. Competencies/Skills Acquired from NEUST

\begin{tabular}{|l|c|c|}
\hline $\begin{array}{l}\text { Competencies/ Skills } \\
\text { Acquired }\end{array}$ & f & \% \\
\hline Entrepreneurial skills & 61 & 66.30 \\
\hline Conceptual skills & 36 & 39.13 \\
\hline Managerial skills & 73 & 79.35 \\
\hline Critical solving skills & 78 & 84.79 \\
\hline Human relation skills & 59 & 64.13 \\
\hline Information (technology) skills & 48 & 52.17 \\
\hline
\end{tabular}

The skills acquired in NEUST were found very useful. Skills include critical solving skills, managerial skills and entrepreneurial skills. The graduates became more creative and able to solve problems, formulate processes and understand the relationship between ideas, concepts, patterns, and symbols. Also, the graduates turned to be competitive, good managerial skills and can assume the risks in business aspects. These characteristics were very beneficial to the respondents since employers always like an employee that is skilled. Thus, this will help them to have a good and reliable source of income [9].

Table 8. School-related factors to the job placement

\begin{tabular}{|c|c|c|c|c|}
\hline \multirow{2}{*}{$\begin{array}{l}\text { Relevance of school- } \\
\text { related factors to job } \\
\text { placement }\end{array}$} & \multicolumn{2}{|c|}{ Important } & \multicolumn{2}{|c|}{$\begin{array}{c}\text { Very } \\
\text { important }\end{array}$} \\
\hline & $\mathbf{f}$ & $\%$ & f & $\%$ \\
\hline $\begin{array}{l}\text { The teacher has good } \\
\text { communication skills }\end{array}$ & 14 & 15.22 & 78 & 84.79 \\
\hline $\begin{array}{l}\text { The teacher has mastery } \\
\text { of the subject }\end{array}$ & 20 & 21.74 & 72 & 78.26 \\
\hline $\begin{array}{l}\text { The teacher conducts } \\
\text { himself/herself in a } \\
\text { professional manner }\end{array}$ & 6 & 6.52 & 86 & 93.48 \\
\hline $\begin{array}{l}\text { Teacher relates subjects } \\
\text { to the practical corporate } \\
\text { situation }\end{array}$ & 4 & 4.35 & 88 & 95.65 \\
\hline
\end{tabular}

It is very interesting to note that on the relevance of schoolrelated factors to job placement to be "very important" to the graduates focused on teachers; relates subjects to the practical corporate situation $95.65 \%$, conducts himself/herself in a professional manner $93.48 \%$, and teacher has a good communication skills $84.79 \%$. 
V. CONCLUSION AND RECOMMENDATION

Majority of the respondents are gainfully employed.Their employment status improved from contractual to regular employment, coupled with work promotion.

Likewise, professional advancement, the reputation of the school/training institution and institutional requirements were the top reasons why they studied in NEUST.

Further, competencies/skills like critical solving skills, human relation skills and conceptual skills which they considered very useful.A school-related factor such as teacherrelates subjects to the practical corporate situation; teacher conducts himself in a professional manner and the teacher has a good communication skill, were considered very important by the respondents.

The finding shows the competitiveness of NEUST as an educational institution where faculty are qualified and competitive. The MBA-Ph.D. contributed much to the professional growth in the graduates' career. Nonetheless, a follow-up investigation to study and explore the performance [10] of the MBA and PH.D. graduates in their workplace was recommended by the researchers to further strengthen the findings of this research.

\section{REFERENCES}

[1] Marilou P. Pascual, PH. D.,(2016), Impact Of Acquired Knowledge, Skills And Abilities Through Studying At Nueva Ecija University of Science And Technology Graduate School.

[2] Adelaida C. Gines, Ph.D., (2015), Tracer Study of PNU Graduates.American International Journal of Contemporary Research.Vol. 4 No. 3; March 2014.

[3] NORM A L. MENEZ, (2014), Tracer Study of the Masters in Business Administration (MBA) Graduates from 2008-2012.

[4] Y. Baruch, M. P. Bell, \& D. Gray, Generalist and specialist graduate business degrees: Tangible and intangible value. Journal of Vocational Behavior, 67(1), 2005, 51-68.

[5] Temtime, Z. \& Mmreki,R.(2011).Challenges faced by graduate business education in Southern Africa: Perceptions of MBA participants.Quality Assurance in Education 19(2):110-129 DOI: 10.1108/09684881111125023

[6] Maribeth G. Buenviaje, Hadge A. Encio, Rey Fernan Refozar,Adones Anuran, Nestor C. Camello, Jake M. Laguador. (2016). Employability andSkills of MBA Graduates fromLiteratureReview asInput to Student Development Program.Quest Journals.Journal of Research in Business and Management. Volume 4 Issue 5(2016) pp: 16-21 ISSN(Online) : 2347-3002

[7] Subia, G.S. (2018). Comprehensible Technique in Solving Consecutive Number Problems in Algebra. Journal of
Applied Mathematics and Physics, 6,447-457. https://doi.org/10.4236/jamp.2018.63041

[8] Subia, Gener S. (2018). Think Like My Teacher (TLMT): A New Method in Assessing Millennial Learners. International Journal of Arts, Humanities and Social Sciences.Volume 3. Issue 1.www.ijahss.com

[9] MARSHALLELAINE, TAN, N.G. (2009) Make Money by Growing Mushrooms Elaine Marshall and N. G (Tan) Nair Rural Infrastructure and Agro-Industries Division Food and Agriculture Organization of the United Nations Rome.

[10] Subia, G. , Amaranto, J. , Amaranto, J. , Bustamante, J. and Damaso, I. (2019) Chess and Mathematics Performance of College Players: An Exploratory Analysis. Open Access Library Journal, 6, 1-7. doi: 10.4236/oalib.1105195 